\title{
Effects of Management Practices and Land Use on Biological and Enzymatic Attributes of an Agricultural Area
}

\author{
Luciana S. Barros ${ }^{1}$, Valdinar F. Melo ${ }^{1}$, Zachary N. Senwo ${ }^{2}$, Ariane Evald ${ }^{1}$, Raphael Henrique S. Siqueira ${ }^{3}$, \\ Ricardo Manuel Bardales ${ }^{4} \&$ Taline Katle de Oliveiras Nunes ${ }^{1}$ \\ ${ }^{1}$ Department of Soils and Agricultural Engineering, Federal University of Roraima, Roraima, Brazil \\ ${ }^{2}$ Alabama A\&M University, Alabama, USA \\ ${ }^{3}$ Federal Institute of Education Science and Technology of Amazonas, Brazil \\ ${ }^{4}$ Instituto de Investigaciones de la Amazonia Peruana, Brazil \\ Correspondence: Luciana S. Barros, Department of Soils and Agricultural Engineering, Federal University of \\ Roraima, Roraima, Brazil. Tel: 55-95-981-146-284. E-mail: luciana.barros@ifrr.edu.br; \\ luciana.barros72@gmail.com
}

Received: March 17, $2018 \quad$ Accepted: April 18, $2018 \quad$ Online Published: May 15, 2018

doi:10.5539/jas.v10n6p110 URL: https://doi.org/10.5539/jas.v10n6p110

The research is financed by Amazon Research Support Foundation (FAPEAM) and Coordination of Improvement of Higher Level Personnel (CAPES).

\begin{abstract}
A series of anthropogenic approaches, including burning practices and soil disturbances as soil cover removal, plowing and harrowing were experimentally undertaken to mimic land conversion for agricultural production in northern Amazonia. These manipulations led to changes in soil biological and biochemical properties. To reduce knowledge gaps concerning land conversion in the Amazon, the study objective was to evaluate the influence of land use and management practices on the biological attributes and enzymatic activity of the soil in Tepequem, a settlement in north of the Amazon, Brazil. Tepequem was chosen for being highly representative in terms of land use and management patterns in the region. Microbial biomass carbon (MBC), soil basal respiration (SBR), metabolic quotient $\left(\mathrm{qCO}_{2}\right)$ and enzymatic activity were analyzed. Land use changes resulted in alterations to soil quality. The spontaneous plants found on degraded pasture ensured system diversification, protection and organic contribution, facilitating resumption of ecological balancing of the soil. Good soil quality in managed pasture was attributed to the maintenance of soil cover, provided by grasses, and the absence of soil rotation. Burning, soil disturbances and lack of cover negatively influenced the biological and enzymatic activity in sites that were preparation, deforested and burnt. Chemical attributes are significant factors influencing soil quality and health at subsistance plantation. $\mathrm{MBC}$, $\mathrm{qMIC}$ and $\mathrm{qCO}_{2}$, acid phosphatase, $\beta$-glucosidase and urease were the most sensitive parameters of differentiation of sites in preparation from those of native vegetation and pastures.
\end{abstract}

Keywords: soil disturbance, degraded pasture, urease, $\beta$-glucosidase, acid phosphatase

\section{Introduction}

Between 1970 and 1990, a government-sponsored settlement program in Amazonia resulted in extensive alterations of regional landscapes (Barbosa, 1993). In northern Roraima, this resulted in dozens of agricultural settlements in forest areas with inadequate land policy and significant increase in deforestation (Barni et al., 2012). The lack of technical assistance and unavailability of rural extension support to the settlers have contributed heavily to land degradation, since the great majority of settlers still use a low-tech slash-and-burn system, with ashes used for soil fertilization (Melo et al., 2006).

During the process of conversion of natural ecosystems into agricultural areas, soil loosed its vegetation cover following land clearing, burning (Fearnside et al., 2013). It is subjected to constant soil tillage (Zuber \& Villamil, 2016), reduced organic matter (Raiesi \& Baheshti, 2015), changes physical and chemical properties, and strong 
reductions in microbiological diversity (Acosta Martinez et al., 2007), all of which have implications on soil health, and consequently on environmental quality.

The use of highly-sensitive indicators has been proposed because landscape changes can potentially lead to reduction and possible degradation of soil quality and health. Techniques of evaluation of the indicators involve measuring soil chemical attributes, the flux and stock of carbon, as well as levels of biological activity that includes microbial activity, microbial biomass and composition, and enzymatic activities (Anderson \& Domesch, 2010).

Soil microbial biomass is often considered a strong indicator of soil health and plays a significant role in nutrient cycling, organic waste decomposition and pollutant degradation (Kaschuk et al., 2010). Assessing microbial biomass does not indicate the "health" condition of the microorganisms, however; other research parameters, such as basal respiration and metabolic and microbial quotients are needed for such estimations (Matsuoka et al., 2003). According to Mangalassery et al. (2015), soil basal respiration (SBR) is closely tied to abiotic soil conditions such as humidity, temperature and aeration, which are, in turn, strongly influenced by land use and management practices. In fact, absence of burning, maintenance of plant cover can help guarantee high levels of microorganism activity.

Soil enzymes are primarily of microbial origin and, due to their sensitivities to environmental changes (Raiesi \& Baheshti, 2015). When correlated with other soil properties like $\mathrm{pH}$, available phosphorus content and soil biomass carbon, this might provide information on how soil use may affect their quality (Silva et al., 2009).

Studies of altered areas by agricultural and livestock activities in the northern Amazonia, which subsidize the conservation-oriented soil management, are still very scarce. Regarding this absent of information in this region, we aim with this work to evaluate the influence of land use and management practices on the chemical attributes, biological and enzymatic activities of soils from altered areas of the Tepequém settlement, Roraima, Brazil.

\section{Material and Methods}

The study was carried out in the Tepequém settlement $\left(3^{\circ} 31^{\prime}\right.$ and $3^{\circ} 48^{\prime} \mathrm{N}, 61^{\circ} 30^{\prime}$ and $\left.62^{\circ} 00^{\prime} \mathrm{W}\right)$, Amajari municipality, Roraima State, in the extreme north of Amazonian Brazil. The area forms part of the Trairão river basin (Figure 1).

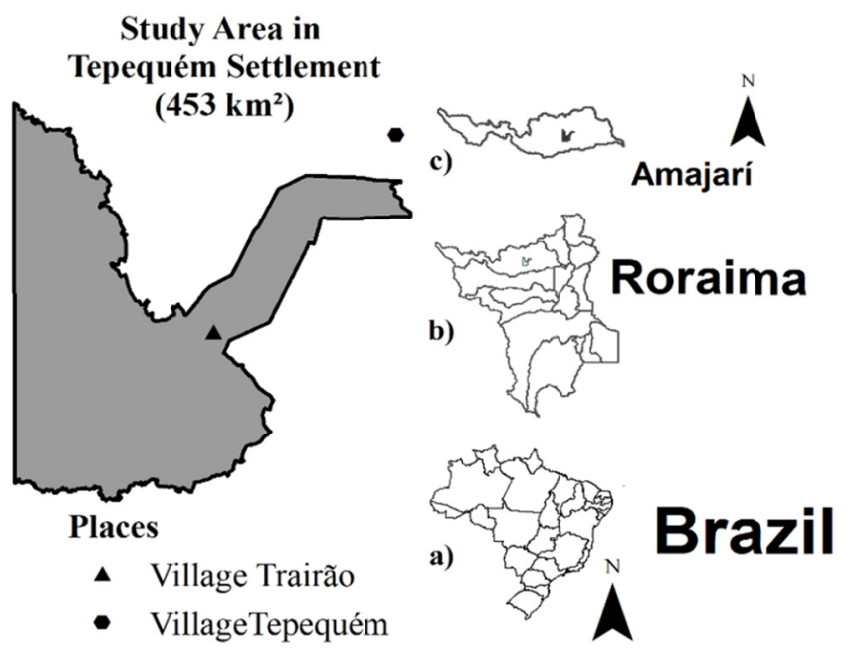

Figure 1. Location of the Tepequém settlement the study area

According to the Köppen classification, regional climate is Am, with two seasons i.e. a dry season from December to April and rainy season from May to November, annual rainfall varies between 1700 and $2000 \mathrm{~mm}$, and temperatures between $20-32{ }^{\circ} \mathrm{C}$ (Barbosa, 1997). Regional relief consists of gentle undulating hills associated with the dissected plateau of northern Amazonia, which consists of volcanic rocks from two formations, pedra pintada (orthopyroxene, clinopyroxene, hornblende-biotite, quartz-diorite and tonalite) and suite trairão (hornblende, biotite granodiorites and tonalites with associated diorite quartz and gneiss). The altitudes vary between 250 and $600 \mathrm{~m}$ above sea level (CPRM, 2010). Native vegetation consists of dense ombrophylous forest with intergrades into seasonal rest/ombrophilous forest (RADAMBRASIL, 1975). The soils 
studied are classified as Yellow Argisol (Hapludult) and Red Nitosol (Typic Hapludalf), according to the Brazilian Soil Classification System (Santos et al., 2013), Ultisol and Alfisol according to a Soil Taxonomy (Soil Survey Staff, 2014).

The study area was chosen for being highly representative of the study region in general, in terms of land use and management patterns adopted, as well as of native vegetation. The study sites consisted of (i) two areas of pastures, (ii) two areas in preparation for conventional tillage (turned soil and a newly burnt area), (iii) one subsistence farming area (cassava, banana and papaya), and (iv) native forest cover area, which served as a control (Table 1).

Soil samples were collected in two different periods: dry period (April 2015) and wet period (July 2015). In each study area, a block of approximately $100 \times 100 \mathrm{~m}\left(10,000 \mathrm{~m}^{2}\right)$, subdivided into 4 plots of $50 \times 50 \mathrm{~m}\left(2,500 \mathrm{~m}^{2}\right)$ was set-up, to provide repetitions of each treatment. In each plot, three sub-samples observations were collected. Holes $0.50 \times 0.50 \times 0.50 \mathrm{~m}$ in extent were excavated, and samples taken at 0-5 and 0.05-0.15 m, with 6 samples per plot, totaling 24 samples per study area. For the biological and enzymatic analyzes, samples were stored at $4{ }^{\circ} \mathrm{C}$ in plastic bags in a freezer in the UFRR soil management laboratory.

Table 1. Characteristics of land uses in the Tepequém settlement during the dry season (April/2015) and during the rainy season (July/2015)

\begin{tabular}{|c|c|}
\hline Land use & Characteristics \\
\hline Native vegetation $\mathrm{P} 1$ & Hapludult (dystrofic yellow argisol) soil with dense lowland rainforest vegetation. \\
\hline Degraded pasture $\mathrm{P} 2$ & $\begin{array}{l}\text { Hapludult (dystrofic yellow argisol) soil under grass pasture (Brachiaria brizantha A. Rich), and } \\
\text { submitted to extensive and continuous cattle grazing without fertility management, and without } \\
\text { rotation. In the dry season, there was a dry covering, interspersed with spontaneous plants (jurubeba: } \\
\text { Solanum paniculatum L.; lobeira: Solanum lycocarpum A. St.-Hil.; vassourinha: Scoparia dulcis L.; } \\
\text { malícia: Mimosa pudica L.). With paths indicating intense trampling and laminar erosion. In the rainy } \\
\text { season, the pasture had a high populations of spontaneous plants, with a low presence of cattle in the } \\
\text { area, which is regionally characteristic of a degraded pasture. }\end{array}$ \\
\hline Managed pasture P3 & $\begin{array}{l}\text { Hapludult (dystrofic yellow argisol) soil under pasture of Brachiaria brizantha since 1992, without } \\
\text { liming and fertilization. In the dry season, grass height was between } 0.20 \text { to } 0.50 \mathrm{~m} \text {, very uniform, } \\
\text { with few spontaneous plants. Cattle grazing was in rotation and animals were spent } 90 \text { days per plot. } \\
\text { In the wet season, ungrazable areas developed due to intense trampling effects. }\end{array}$ \\
\hline Plots in preperation $\mathrm{P} 4$ & $\begin{array}{l}\text { Hapludult (dystrofic yellow argisol) soil, with bare soil surface. Area prepared for corn planting with } \\
\text { plowing, tilling and acidity correction. Two years earlier it had been used as cattle pasture. In the wet } \\
\text { season } 90 \text { days after the first sampling, it remained uncovered, because sown corn seeds had not } \\
\text { germinated. }\end{array}$ \\
\hline $\begin{array}{l}\text { Plots in preperation } \\
\text { (deforestation and burning) P5 }\end{array}$ & $\begin{array}{l}\text { Hapludult (dystrofic yellow argisol) soil with native vegetation recently deforested and burned. } \\
\text { Presence of felled trees on the ground, of ash and areas still in combustion. Plant species present } \\
\text { included pau-rainha (Centrolobium paraense), ingá (Inga spp.), kapok (Ceiba pentandra L.), lobeira } \\
\text { (S. lycocarpum). }\end{array}$ \\
\hline Subsistance plantation P6 & $\begin{array}{l}\text { Typic Hapludalf (eutrophic red nitosol) soil under subsistence farming of banana (Musa spp.), cassava } \\
\text { (Manihot esculenta Crantz), maize (Zea mays L.) and papaya (Carica papaya L.). Presence of weeds } \\
\text { between plants, however, with uneven cover, presence of coal indicating the use of fire for the } \\
\text { preparation of the area. } 90 \text { days after the second data collection the area had little plant cover. }\end{array}$ \\
\hline
\end{tabular}

The $\mathrm{pH}\left(\mathrm{H}_{2} \mathrm{O}\right)$ was measured in a 1:2.5 (soil:water) solution, $\mathrm{Ca}^{2+}$ and $\mathrm{Mg}^{2+}, \mathrm{K}^{+}$and available $\mathrm{P}$ were extracted by the double-acid solution $\left(\mathrm{HCl} 0.05 \mathrm{M}+\mathrm{H}_{2} \mathrm{SO}_{4} 0.0125 \mathrm{M}\right.$ ), $\mathrm{K}^{+}$was determined by flame photometry and $\mathrm{P}$ by colorimetrically. Cation exchange capacity (CEC) was calculated from the results sorptive complex analysis, all determined as described by EMBRAPA (2009). Analyzes for organic soil carbon (SOC) was performed via dry methods in a Vario El III elemental analyzer (Elementar Analysensysteme GmbH, Germany).

Soil microbial biomass carbon (MBC) was determined using the chloroform-fumigation-extraction method (Vance et al., 1987), and soil basal respiration (SBR) according to Jenkinson and Powlson (1976). The metabolic quotient $\left(\mathrm{qCO}_{2}\right)$ was the ratio of SBR per unit over the $\mathrm{MBC}$ per unit time, and the microbial quotient (qMIC) from the $\mathrm{MBC} / \mathrm{SOC}$ ratio. To determine enzymatic activity, samples of the first $0.15 \mathrm{~m}$ of soil, sieved through a $4 \mathrm{~mm}$ mesh, and with vegetal fragments eliminated were used. $\beta$-glycosidase and acid phosphatase enzymes were determined using $1 \mathrm{~g}$ of soil with their respective extractors ( $p$-Nitrophenyl-b-D-glucopyranoside and $p$-Nitrophenyl phosphate), following Tabatabai (1994). Urease activity was assessed as described by Kandeler and Gerber (1988), using the rate of urea hydrolysis from a $0.5 \mathrm{~g}$ soil sample, and using calorimetry at $660 \mathrm{~nm}$ to quantify the ammonia released during the incubation period of the soil with urea, without toluene. 
Analysis of variance ( $\mathrm{F}$ test) was used to detect the existence of a difference between land uses (treatments). Tukey test was performed at 1 and $5 \%$ probability to compared mean values of indicators measured for each of the land uses. Data were submitted to principal component analysis (PCA), to determine the relative importance of the analysed characteristics (Singh, 1981). Subsequently, and using INFOGEN software, version 2013 (Balzarini \& Di Rienzo, 2013), the discarding variables method was used to eliminate those variables with smallest contribution to variability.

\section{Results and Discussion}

Study area soils had high to medium acidity, low fertility, but were high in $\mathrm{P}$ and $\mathrm{K}$, especially in the areas affected by the fires (Table 2).

Conversion of forest (P1) to the systems represented by the P2, P3, P4 and P5 sites promoted changes in the chemical properties of soils. The high acidity at P1, P2, P3, P4 and P5 reflect the advanced degree of soil weathering in these areas. However, the highest $\mathrm{pH}$, observed in the initial depth of soil from the P5 site, is derived from the release of bases in the ash resulting from burning in the area. Similar results having been obtained by Melo et al. (2006) with soils from agricultural plots of Apiaú, Roraima. The much lower acidity observed at P4 in the 0.0-0.05 m layer is related to addition to the soil of dolomitic limestone as part of a soil management regimen. The average $\mathrm{pH}$ of the $\mathrm{P} 6$ site is a consequence of the high base contents, inherent to the soil class there (Typic Hapludalf), a fact already recorded by other studies (Melo et al., 2006; Melo \& Schaefer, 2009). High surface layer acidity at $\mathrm{P} 3$ and $\mathrm{P} 2$ is a consequence of soil impoverishment, both by weathering and because of soil exhaustion due to its use as pasture, without replenishment with chemical or organic fertilizers.

The potential acidity observed in the study areas is like that reported by Melo et al. (2006) in the evaluation of Ultisol under forest and indigenous cultivation areas in the Yanomami Indigenous Land, on the mid-Catrimani river, Roraima. This indicates it is the result of natural process, but accelerated by the incorrect uses of the soils, especially without applying a chemical corrective for the natural acidity.

Levels of exchangeable cations $\left(\mathrm{Ca}^{2+}, \mathrm{Mg}^{2+}\right.$ and $\left.\mathrm{K}^{+}\right)$and available $\mathrm{P}$ found on the surface, especially at the $\mathrm{P} 5$ site, are indicative of the contribution that occurs when ashes are used to the increase nutrient availability. By accelerating the organic matter mineralization processes, the burning of vegetation temporarily increases the exchangeable elements content, briefly providing more favorable conditions of soil fertility in the superficial layer of the soil. However, as reported by Pomianoski et al. (2006), this decreases to very low values in a few years.

Table 2. Chemical properties of human-altered soils from the Tepequém Settlement-Amajari-Roraima-State, northern Brazil

\begin{tabular}{|c|c|c|c|c|c|c|c|}
\hline Soil Study Areas & $\mathrm{pH}\left(\mathrm{H}_{2} \mathrm{O}\right)$ & $\mathrm{P}$ & $\mathrm{H}+\mathrm{Al}$ & $\mathrm{Ca}^{2+}$ & $\mathrm{Mg}^{2+}$ & $\mathrm{K}^{+}$ & CEC \\
\hline & & $\mathrm{mg} \mathrm{kg}^{-1}$ of soil & ------------ & ------------ & $\mathrm{nol}_{\mathrm{c}} \mathrm{kg}^{-1}$ of & pil ----------- & ---------- \\
\hline \multicolumn{8}{|l|}{$0.0-0.05 \mathrm{~m}$} \\
\hline P1 & $5.00 \mathrm{Acd}$ & $4.95 \mathrm{Ad}$ & $1.69 \mathrm{Ac}$ & $0.59 \mathrm{Ab}$ & $0.72 \mathrm{Ab}$ & $0.08 \mathrm{Ac}$ & $3.14 \mathrm{Ad}$ \\
\hline $\mathrm{P} 2$ & $4.86 \mathrm{Ad}$ & $7.73 \mathrm{Ab}$ & $2.63 \mathrm{Ab}$ & $0.80 \mathrm{Ab}$ & $1.04 \mathrm{Ab}$ & $0.19 \mathrm{Ab}$ & $4.72 \mathrm{Abc}$ \\
\hline P3 & $5.41 \mathrm{Ab}$ & $8.70 \mathrm{Ab}$ & $2.23 \mathrm{Aab}$ & $0.83 \mathrm{Ab}$ & $0.85 \mathrm{Ab}$ & $0.12 \mathrm{Abc}$ & $4.09 \mathrm{Ac}$ \\
\hline P4 & $5.01 \mathrm{Acd}$ & $7.10 \mathrm{Abc}$ & $2.55 \mathrm{Ab}$ & $1.43 \mathrm{Aa}$ & $0.99 \mathrm{ABb}$ & $0.21 \mathrm{Ab}$ & $5.42 \mathrm{Ab}$ \\
\hline P5 & $5.13 \mathrm{Ac}$ & $17.40 \mathrm{Aa}$ & $4.43 \mathrm{Aa}$ & $0.94 \mathrm{Ab}$ & $1.08 \mathrm{Ab}$ & $0.20 \mathrm{Ab}$ & $6.71 \mathrm{Aa}$ \\
\hline P6 & $6.14 \mathrm{Aa}$ & $5.73 \mathrm{Abc}$ & $2.03 \mathrm{Aab}$ & $1.80 \mathrm{Aa}$ & $2.28 \mathrm{Aa}$ & $0.55 \mathrm{Aa}$ & $6.73 \mathrm{Aa}$ \\
\hline \multicolumn{8}{|l|}{$0.05-0.15 \mathrm{~m}$} \\
\hline $\mathrm{P} 1$ & $5.00 \mathrm{Acd}$ & $4.95 \mathrm{Ad}$ & $1.82 \mathrm{Abc}$ & $0.38 \mathrm{Ab}$ & $0.38 \mathrm{ABc}$ & $0.08 \mathrm{Ab}$ & $2.71 \mathrm{Ad}$ \\
\hline P2 & $4.86 \mathrm{Ad}$ & $7.73 \mathrm{Ab}$ & $2.53 \mathrm{Ab}$ & $0.38 \mathrm{Bb}$ & $0.63 \mathrm{Bbc}$ & $0.11 \mathrm{Ab}$ & $3.71 \mathrm{Bc}$ \\
\hline P3 & $5.41 \mathrm{Ab}$ & $8.70 \mathrm{Ab}$ & $1.43 \mathrm{Bc}$ & $0.50 \mathrm{ABb}$ & $0.56 \mathrm{Ac}$ & $0.06 \mathrm{ABb}$ & $2.61 \mathrm{Bd}$ \\
\hline $\mathrm{P} 4$ & 5.01 Acd & $7.10 \mathrm{Abc}$ & $2.29 \mathrm{Ab}$ & $0.45 \mathrm{Bb}$ & $1.12 \mathrm{Aab}$ & $0.12 \mathrm{Bb}$ & $3.98 \mathrm{Bbc}$ \\
\hline P5 & $5.13 \mathrm{Ac}$ & $17.40 \mathrm{Aa}$ & $3.93 \mathrm{Aa}$ & $0.20 \mathrm{Bb}$ & $0.34 \mathrm{Bc}$ & $0.11 \mathrm{Bb}$ & 4.65 Bab \\
\hline P6 & $6.14 \mathrm{Aa}$ & $5.73 \mathrm{Abc}$ & $2.47 \mathrm{Ab}$ & $1.16 \mathrm{Ba}$ & $1.35 \mathrm{Ba}$ & $0.35 \mathrm{Ba}$ & $5.38 \mathrm{Ba}$ \\
\hline
\end{tabular}

Note. $\mathrm{P} 1=$ Native forest; $\mathrm{P} 2=$ degraded pasture; $\mathrm{P} 3=$ managed pasture $\mathrm{P} 4=$ area prepared for maize cultivation; P5 $=$ area under preparation, recently deforested and burned; P6 = subsistence planting. Values followed by the same letters showed no statistical difference (Tukey test, $\mathrm{p}>0.01$ ). 
Study area SOC levels were not affected by soil use form $(p>0.01)$, but the layers were different from each other (Figure 2).

The mean SOC contents in the 0.0-0.05 m layer of site P5 may be due to the charcoal generated during burning. According to Hobley et al. (2017) this is quickly incorporated into the soil mass, resulting in deposits that can contribute to long-term SOC. C incorporation at sites P2 and P3 comes from decomposition of the pasture root system and the efficient nutrient cycling of the grasses. This fact is related to the high $\mathrm{C} / \mathrm{N}$ ratio, and lower rate of decomposition of root tissues, which itself is a result of their higher lignin content. At P2 this was supplemented by the direct introduction to the soil matrix of grass root products and of the spontaneous plants also present there. Faria et al. (2010), when evaluating the influence of soil management on chemical and physical properties in a toposequence in the Araguaia river basin, Tocantins did not observe a significant variation in the SOC content in the pasture areas evaluated in relation to the area of native vegetation, and attributed this to the incorporation of $\mathrm{C}$ from the decomposition of the pasture-grass root system.

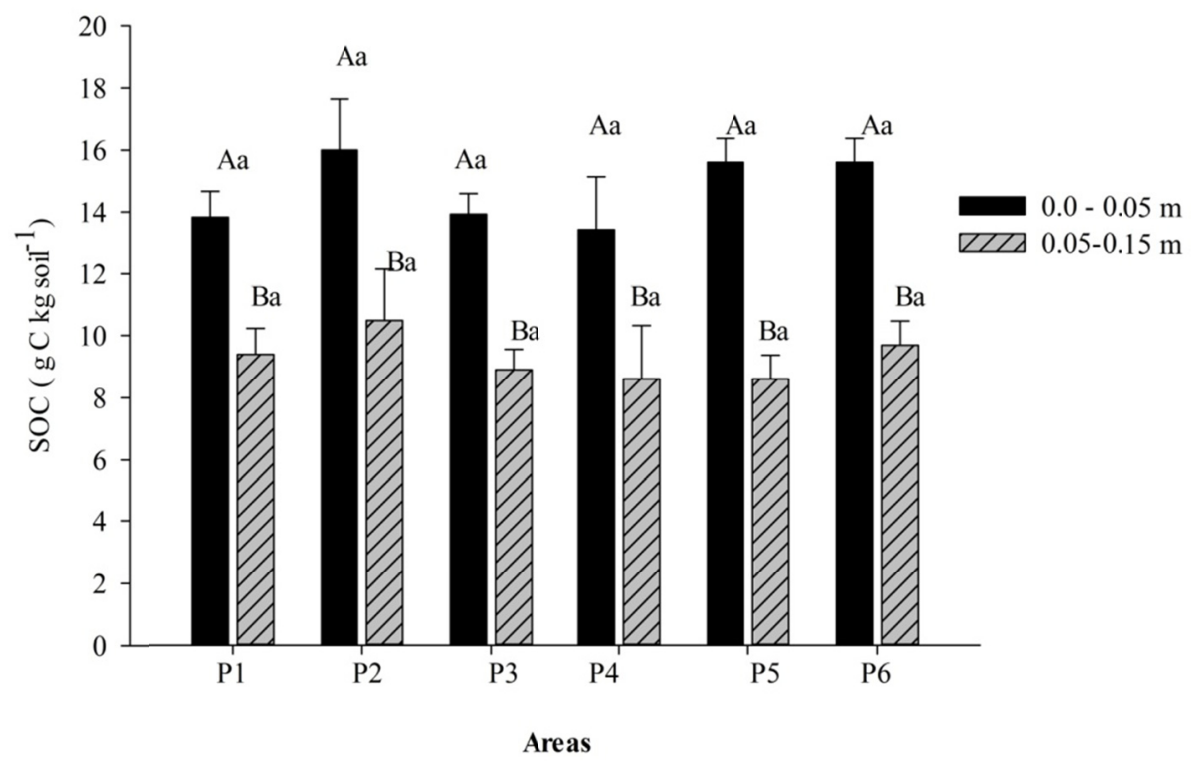

Figure 2. Soil organic carbon (SOC) between the areas and between the layers

Note. $\mathrm{P} 1$ = Native forest; $\mathrm{P} 2$ = degraded pasture; $\mathrm{P} 3=$ managed pasture; $\mathrm{P} 4=$ area prepared for maize cultivation; P5 = area under preparation, recently deforested and burned; P6 = subsistence planting. Averages followed by the same letter, uppercase between the depths and lowercase between the areas, do not differ by Tukey ( $p>$ $0.01)$.

Another factor favoring the increase of the $\mathrm{C}$ in the first few centimeters of the soil at site P2 was the biological activity of the mesofauna and macrofauna, especially termites, whose activity (including construction of chambers on the soil surface) was observed at this site. According to Lal (1988), have important ecological role, especially in turning-over and humidifying soil organic matter.

Site $\mathrm{P} 5$ showed a 54\% reduction in MBC in comparison to P1 in the dry season $(\mathrm{p}<0.01)$, while the other sites did not show any significant difference (Table 3). In the wet season sites P3, P4 and P5 showed reduction in the order of $47 \%, 57 \%$ and $73 \%$ compared to P1 $(\mathrm{p}<0.01)$. Sites P1, P2, P3 and P6 showed statistical differences between the dry and wet seasons, with a $19 \%$ and $23 \%$ increase at sites P1 and P2, respectively, and a reduction of $51 \%$ and $42 \%$, respectively, at sites P3 and P6. 
Table 3. Values for microbial biomass carbon (MBC), microbial quotient (qMIC) in two seasons (dry and wet) from soils from human-altered areas of the Tepequém Settlement, depth $0.0-0.15 \mathrm{~m}$

\begin{tabular}{llcccc}
\hline \multirow{2}{*}{ Soil Study Areas } & \multicolumn{2}{c}{ MBC } & & \multicolumn{2}{c}{ qMIC } \\
\cline { 2 - 3 } P1 & Dry season & Wet season & & Dry season & Wet season \\
P2 & $233 \mathrm{Bab}$ & $288 \mathrm{Aa}$ & & $2.10 \mathrm{Bab}$ & $2.68 \mathrm{Aa}$ \\
P3 & $238 \mathrm{Bab}$ & $311 \mathrm{Aa}$ & & $1.83 \mathrm{Babc}$ & $2.39 \mathrm{Aa}$ \\
P4 & $310 \mathrm{Aa}$ & $152 \mathrm{Bb}$ & & $2.48 \mathrm{Aa}$ & $1.26 \mathrm{Bb}$ \\
P5 & $144 \mathrm{Abc}$ & $125 \mathrm{Ab}$ & & $1.36 \mathrm{Abc}$ & $1.60 \mathrm{Ab}$ \\
P6 & $108 \mathrm{Ac}$ & $78 \mathrm{Ab}$ & & $1.06 \mathrm{Ac}$ & $0.72 \mathrm{Ab}$ \\
\hdashline CV $(\%)$ & $193 \mathrm{Abc}$ & $111 \mathrm{Bb}$ & & $1.88 \mathrm{Aabc}$ & $1.05 \mathrm{Bb}$ \\
\hline
\end{tabular}

Note. Values followed by the same letters, upper case for depths, lowercase for sites showing no statistical difference (Tukey test, $\mathrm{p}>0.01$ ). P1 = Native forest; P2 = degraded pasture; P3 = managed pasture; $\mathrm{P} 4=$ area prepared for maize cultivation; P5 = area under preparation, recently deforested and burned; P6 = subsistence planting.

The use of fire at site $\mathrm{P} 5$ resulted in losses of $\mathrm{CO}_{2}$ preventing conversion of soil $\mathrm{C}$ into $\mathrm{MBC}$, causing a decrease in microbiological activity at this study site. Pomianoski et al. (2006) when evaluating effects of fire as a management tool in an agroforestry system at bracatinga found similar results.

The process of repopulation of site P2 by spontaneous plants intensified during the wet season and made the system more diversified, which was a major stimulus to microorganisms, which used them as a source of energy and carbon for their activities. Plant species diversity and their forms of dispersion directly influence the number and frequency of soil biota interactions. This, in turn, directly and indirectly influences the biological, physical and chemical attributes of the soil, especially via natural vegetation regeneration (Medeiros et al., 2017).

The wet season decline of $\mathrm{MBC}$ at site $\mathrm{P} 3$ and $\mathrm{P} 6$ was due to the reduction in vegetation cover. The remaining of the cattle grazing the $\mathrm{P} 3$ site altered soil conditions, since the area was trampled and lacked covering vegetation. Grazing for prolonged periods may result in vegetation degradation, since this may respond differently to the intensity and frequency of grazing. At site P6, this result may also have been influenced by the withdrawal of subsistence production species and the practice of weeding, common in this type of management, which subjecting the area to stress, promoting losses of C. These results are similar to those of Silva et al. (2012), who compared soil biomass carbon of pasture and subsistence agriculture areas in the Paraíba valley. These authors reported a reduction of up to $63 \%$ in SMB-C in both areas in the wet season.

Study site microbial quotients (qMIC) in different seasons also indicated stress reduction occurred at site $\mathrm{P} 2$ area between the dry and rainy seasons since, with a $23 \%$ increase in qMIC, it remained statistically similar to site P1. qMIC values also revealed the impact suffered at sites P3 and P6, as a function of wet season management practices, with reduction of $49 \%$ and $44 \%$, respectively.

Sites P1, P2 and P5 showered statistical difference $(\mathrm{p}<0.01)$ between the studied layers. At site P2 MBC of soil was highest in the 0.0-0.05 m layer, while at P1 and P5 was highest in the 0.05-0.15 m layer (Figure 3). 


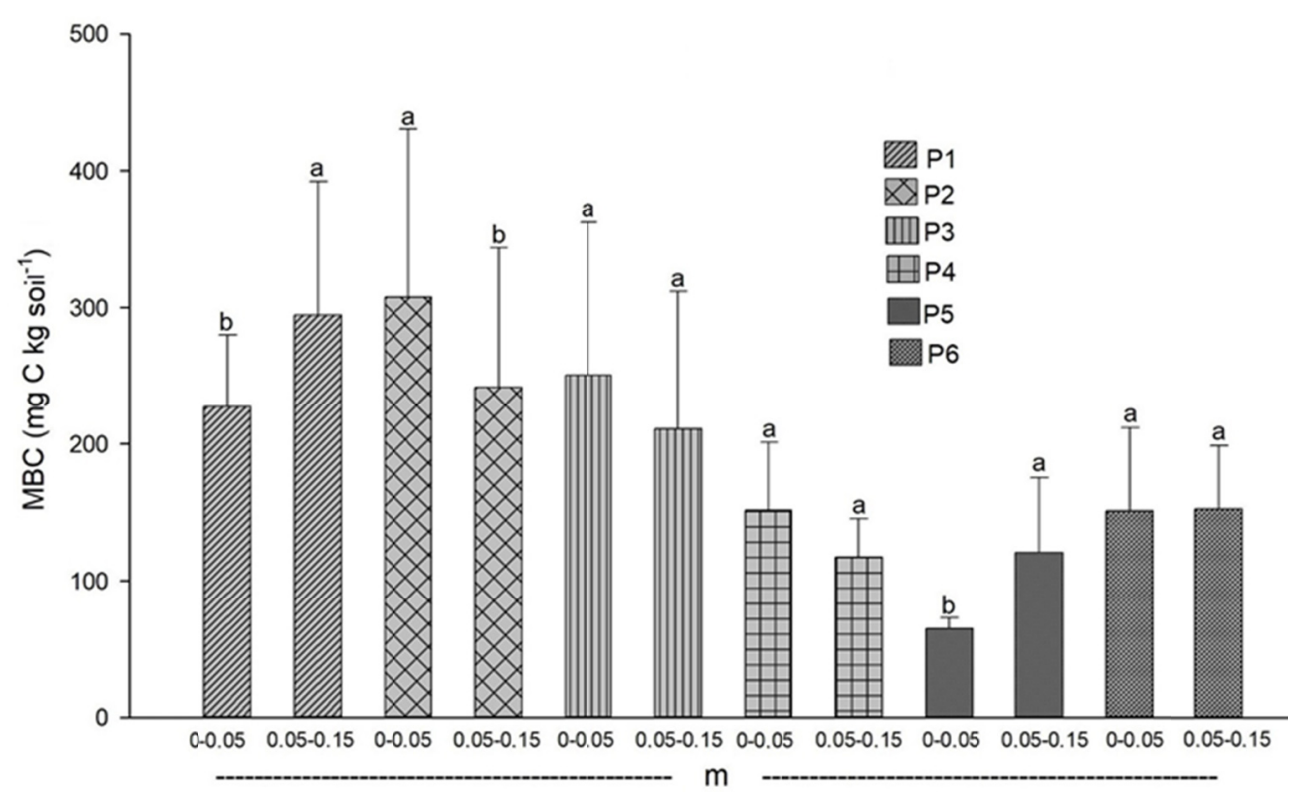

Figure 3. Soil microbial biomass carbon (MBC) at different depths (0.0-0.05 and 0.05-0.15 m) in altered areas at Tepequém Settlement

Note. $\mathrm{P} 1$ = native forest $\mathrm{P} 2$ = degraded pasture; $\mathrm{P} 3$ = managed pasture; $\mathrm{P} 4=$ area prepared for maize cultivation; P5 = area under preparation, recently deforested and burned; P6 = subsistence planting. Values followed by the same letters, upper case for depths, lowercase for sites showing no statistical difference (Tukey test, $p>0.01$ ).

The metabolic quotient $\left(\mathrm{qCO}_{2}\right)$ ratifies the losses suffered in the areas P5, P4 and P6 (Figure 4).

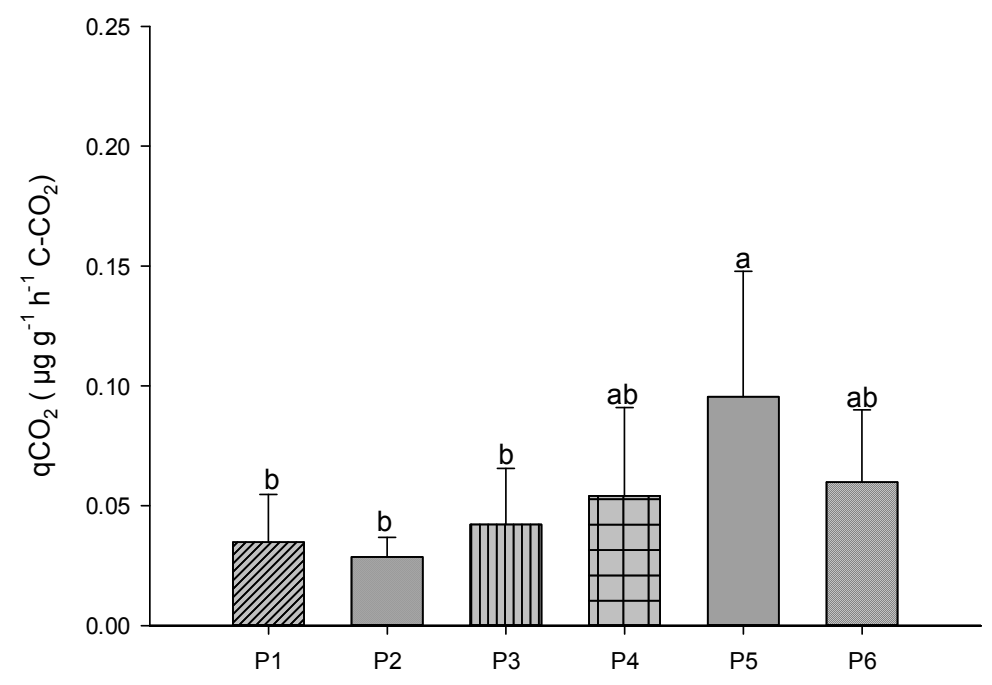

Figure 4. Microbial quotient qMIC in human-altered sites at Tepequém Settlement-Amajari-Roraima

Note. $\mathrm{P} 1$ = native forest; $\mathrm{P} 2$ = degraded pasture; $\mathrm{P} 3=$ managed pasture; $\mathrm{P} 4=$ area prepared for maize cultivation; P5 $=$ area under preparation, recently deforested and burned; P6 = subsistence planting. Values followed by the same letters showed no statistical difference (Tukey test, $\mathrm{p}>0.01$ ).

Although SBR is strongly influenced by abiotic factors, including humidity, temperature and aeration (Lisboa et al., 2012), no differences were observed in SBR values between the studied areas, so this attribute was not a good indicator of soil quality under the current research conditions. 
$\beta$-glicosidase and urease showed a significant interaction effect between the areas and climatic seasons, whereas the acid phosphatase showed significant differences only between the studied areas, and not for seasons. In the wet season $\beta$-glucosidase activity at site $\mathrm{P} 2$ was $163 \%$ higher than at P1. Only sites $\mathrm{P} 2$ and $\mathrm{P} 3$ showed statistical difference between seasons $(\mathrm{p}<0.01)$. In the dry season $\beta$-glucosidase activity at sites $\mathrm{P} 2$ and $\mathrm{P} 3$ exceeded that at P1 by $86 \%$ and $153 \%$, respectively. Other sites showed no difference $(\mathrm{p}>0.01)$ (Table 4$)$. In the wet season $\beta$-glucosidase activity at site $\mathrm{P} 2$ was $163 \%$ higher than at P1. Only sites P2 and P3 showed statistical difference between seasons $(\mathrm{p}<0.01)$. Higher $\beta$-glucosidase activity at P2 and P3 is related to the SOC, MBC and abundance of pasture system roots.

The abundance of roots made available by the grazing system to the soil either from the presence of grasses (P3), or spontaneous plants (P2), favored microbiological activity. Kotroczó et al. (2014) also found this influence occurring during an evaluation of how soil cover (litter and roots) impact activities of the enzymes $\beta$-glycosidase and acid phosphatase. They found that, as a result of greater microbial concentrations, enzymatic activity tends to be more intense in the plant rhizosphere. The wet season increase of $\beta$-glucosidase activity at site $\mathrm{P} 2$ can be explained by the higher incidence of plants. Another positive influence on enzymatic activity at sites P2 and P3 was the absence of soil movement, which favored the protection of aggregates. Positive correlations have been observed between the enzymatic activity and soil aggregates as, according to Raiesi and Beheshti (2015); Zuber and Villamil (2016), these provide protective casings for microorganisms, resulting in greater enzymatic activity.

Site P2 showed extensive termite activity in the first centimeters of the soil, which potentiated increases in soil enzyme activity. Termites contribute to the physical and chemical improvement of the soil, promoting better conditions for organic compound mineralization (Lal, 1988). In contrast to sites P1, P2 and P3, land use and management at sites P4, P5 and P6 exposed the soil, due to a reduction and/or total loss of vegetation cover, so reducing soil protection, and inhibiting the biochemical activity responsible for nutrient cycling. Similar results have been reported by Udawatta et al. (2009), when comparing cultivated areas in the conventional system and agroforestry systems.

Table 4. Enzymatic activity in soils from human-altered areas of Tepequém-Amajari settlement-RR. Samples taken from depths of 0.0 to $0.15 \mathrm{~m}$ in dry and wet seasons

\begin{tabular}{|c|c|c|c|c|}
\hline \multirow{2}{*}{ Soil Study Areas } & \multicolumn{2}{|c|}{$\beta$-glicosidase } & \multicolumn{2}{|c|}{ Urease } \\
\hline & Dry season & Wet season & Dry season & Wet season \\
\hline & \multicolumn{2}{|c|}{----- mg P nitrofenol kg ${ }^{-1}$ soil h$^{-1}$----- } & \multicolumn{2}{|c|}{------ $\mathrm{mg} \mathrm{NH}_{4} \mathrm{~N} \mathrm{~kg}^{-1}$ soil h$^{-1}$------- } \\
\hline $\mathrm{P} 1$ & $38 \mathrm{Ac}$ & $35 \mathrm{Ab}$ & $4 \mathrm{Aa}$ & $2 \mathrm{Ba}$ \\
\hline $\mathrm{P} 2$ & $71 \mathrm{Bab}$ & $92 \mathrm{Aa}$ & $4 \mathrm{Aa}$ & $1 \mathrm{Ba}$ \\
\hline P3 & $96 \mathrm{Aa}$ & $47 \mathrm{Bb}$ & $4 \mathrm{Aa}$ & $2 \mathrm{Ba}$ \\
\hline $\mathrm{P} 4$ & $51 \mathrm{Abc}$ & $51 \mathrm{Ab}$ & $2 \mathrm{Aab}$ & $2 \mathrm{Aa}$ \\
\hline P5 & $34 \mathrm{Ac}$ & $21 \mathrm{Ab}$ & $1 \mathrm{Aab}$ & $2 \mathrm{Aa}$ \\
\hline P6 & $57 \mathrm{Abc}$ & $47 \mathrm{Ab}$ & $2 \mathrm{Aab}$ & $3 \mathrm{Aa}$ \\
\hline $\mathrm{CV}(\%)$ & \multicolumn{2}{|c|}{22.13} & \multicolumn{2}{|c|}{30.63} \\
\hline
\end{tabular}

Note. $\mathrm{P} 1$ = native forest; $\mathrm{P} 2$ = degraded pasture; $\mathrm{P} 3=$ managed pasture; $\mathrm{P} 4=$ area prepared for maize cultivation; $\mathrm{P} 5=$ area under preparation, recently deforested and burned; P6 $=$ subsistence planting. Values followed by the same letters showed no statistical difference (Tukey test, $p>0.01$ ).

The low $\beta$-glucosidase activity found at the P5 and P4 sites may also be associated with exposure of the soil to high temperatures, which occurred in these agroecosystems: by fire at the first, and at the second by solar irradiation, resulting from a total absence of the cover and soil disturbance. According to Boerner et al. (2008), such thermal stress can impair enzymatic kinetics. Accordingly, biodegradability of soil organic matter can be reduced (Kotroczó et al., 2004; Zuber \& Villamil, 2016).

$\beta$-glycosidase action includes converting cellulose to glucose (Mendes et al., 2012). Low $\beta$-glucosidase activity at the P1 site in both periods may be associated with the quantity and quality of the plant matter residues that were being returned to the soil. These are more complex in the native areas than in the agricultural areas, resulting in a consequent reduction in $\beta$-glucosidase activity. Similar effects were reported by Acosta Martinez et al. (2007), in tropical forests and dry and wet seasons. 
There was no statistical between-site differences for urease activity. Though differences between seasons occurred, with a reduction in levels present at sites P1, P2 and P3 from the dry season to the wet. These observations differs from the reports of other authors who have compared activity urease between agricultural areas and those under native vegetation. For example, Raise and Bahesti (2015) reported a 28\% reduction of urease activity in cultivated areas compared to native vegetation areas.

Highest acid phosphatase activity occurred at sites P1, P2 and P3, and no statistical differences existed between these areas $(\mathrm{p}>0.01)$. Acid phosphatase activity at sites P4, P5 and P6 was 33\% lower than at site P1 (Figure 5).

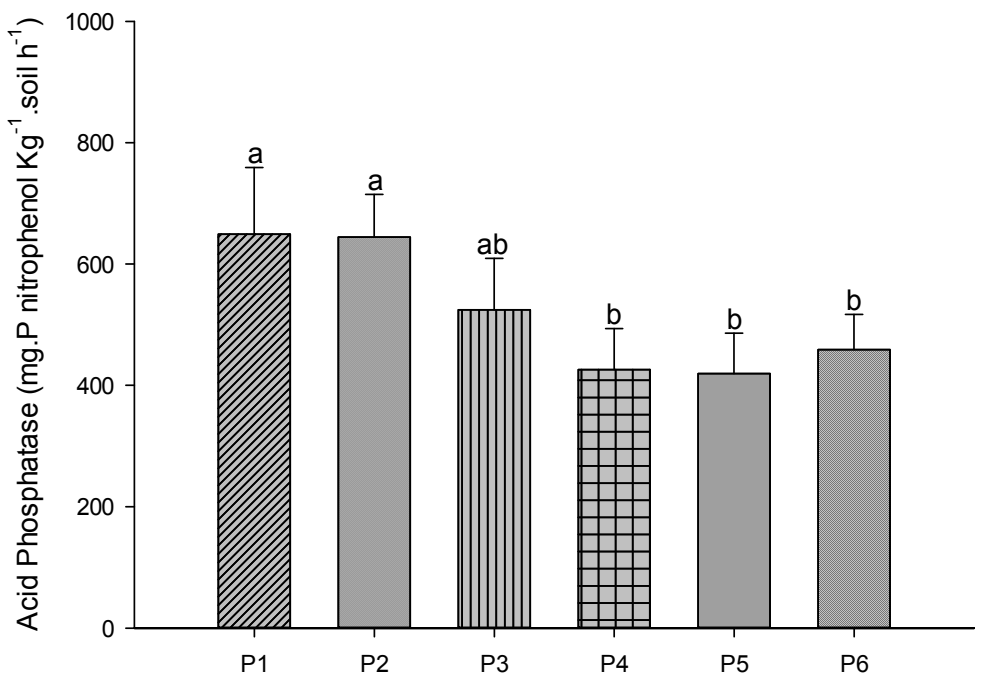

Figure 5. Acid phosphatase activity in human-altered areas at Tepequém Settlement-Amajari-Roraima

Note. $\mathrm{P} 1=$ native forest $\mathrm{P} 2=$ degraded pasture; $\mathrm{P} 3=$ managed pasture; $\mathrm{P} 4=$ area prepared for maize cultivation; P5 $=$ area under preparation, recently deforested and burned; P6 $=$ subsistence planting. Values followed by the same letters showed no statistical difference (Tukey test, $\mathrm{p}>0.01$ ).

Acid phosphatase values found at sites P1, P2 and P3 confirm the positive relationship of this enzyme has with the quantity and quality of SOC. Phosphatase shows increased activity in more preserved environments, where C availability is higher, and temperature, acidity and $\mathrm{pH}$ more favorable, as shown by Silva et al. (2009), in an evaluation of the biological attributes of forest plantation areas. At sites P4, P5 and P6, in addition to the impact of soil management on cover and protection, one of the factors that may have contributed negatively to the activity of this enzyme, especially at P5 was the high levels of P available in the first $0.05 \mathrm{~m}$ of the soil (Table 1). According to Mendes et al. (2012), in P-deficient environments there is a compensation in the soil and plant system that stimulates the production of phosphatase. In consequence, high levels of inorganic $\mathrm{P}$ can inhibit phosphatase action.

Principal Component Analysis revealed a distinction between the biological ( $\mathrm{MBC}, \mathrm{qCO}_{2}, \mathrm{qMIC}$ and SBR) chemical characteristics $\left(\mathrm{pH}, \mathrm{H}+\mathrm{Al}, \mathrm{P}, \mathrm{K}^{+}, \mathrm{SOC}, \mathrm{C} / \mathrm{N}, \mathrm{Ca}+\mathrm{Mg}\right.$ ) and enzymatic ( $\beta$-glycosidase, acid phosphatase and urease) aspects (Figures 6A and 6B).

In the dry season (Figure 6A), the distribution of the selected variables explained $68 \%$ of the total variation for the CP1 and CP2 axes. The CP1 axis explained $42.3 \%$ and the CP2 $25.7 \%$ of these variables, with a correlation of 0.991 between evaluated attributes. The accumulated variables in $\mathrm{CP} 1$ were $\mathrm{qCO}_{2}(0.96), \mathrm{MBC}(-0.89)$, qMIC (-0.85), $\mathrm{pH}(-0.82), \mathrm{H}+\mathrm{Al}(0.80), \mathrm{C} / \mathrm{N}(0.78)$, acid phosphatase $(-0.78),(-0.69)$ and $\beta$-glycosidase $(-0.69)$, which showed the greatest variations, differing for the sites P4 and P5, located in the lower right of the quadrant, and P2, P3 and P1 areas, located in the upper and lower left of the quadrant. The accumulated variables in CP2 were urease (0.78); SOC (-0.73), $\mathrm{Ca}+\mathrm{Mg}(0.71), \mathrm{P}(-0.64)$, SBR (0.58), $\mathrm{H}+\mathrm{Al}(0.54)$ and $\mathrm{K}^{+}(0.47)$, and were linked to site $\mathrm{P} 6$, in the upper left quadrant.

In the wet season (Figure 6B), the PCA produced a total variance of $71.8 \%$ for the $\mathrm{CP} 1$ and $\mathrm{CP} 2$ axes. The CP1 axis explained $45.1 \%$ of this variance and $\mathrm{CP} 226.7 \%$, with a correlation of 0.908 . Accumulated variables in $\mathrm{CP} 1$ were $\mathrm{qCO}_{2}(0.98)$, urea (-0.97), MBC (-0.92), acid phosphatase (-0.90), qMIC (-0.88), C/N (0.71), SBR (-0.60), 
$\mathrm{H}+\mathrm{Al}(0.59)$ and $\beta$-glycosidase (-0.47), which showed the strongest variation, differentiating sites $\mathrm{P} 4$ and $\mathrm{P} 5$ from $\mathrm{P} 1, \mathrm{P} 2$ and $\mathrm{P} 3$. The accumulated variables in $\mathrm{CP} 2$ were $\mathrm{pH}(0.97), \mathrm{H}+\mathrm{Al}(-0.72), \mathrm{Ca}+\mathrm{Mg}(0.84), \mathrm{K}^{+}(0.67)$, SBR (0.65) and P (-0.49), all associated with site P6.

PCA provided a clearer separation between sites P4, P5 and P6 and P1, P2 and P3. This underscored that the different forms of soil management and use and the soil chemical attributes influenced the biological and enzymatic attributes of the soil. Within- and between-site correlations found between the dry and wet seasons permitted the evaluation of which chemical, biological and enzymatic attributes contributed most to the improvement or diminution of soil quality.

(A) 0.0-0.15 m

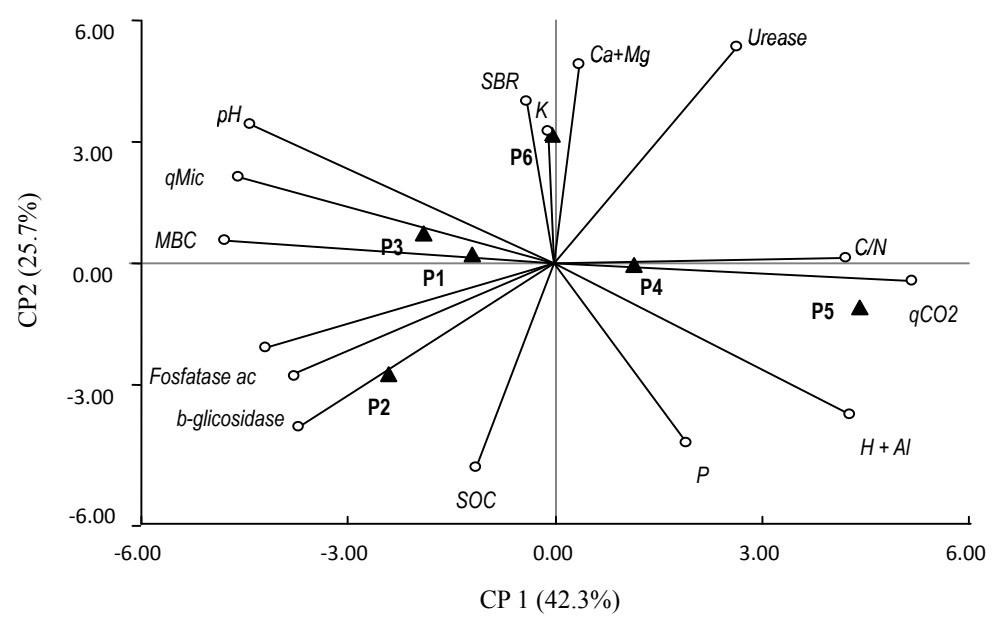

(B) $0.0-0.15 \mathrm{~m}$

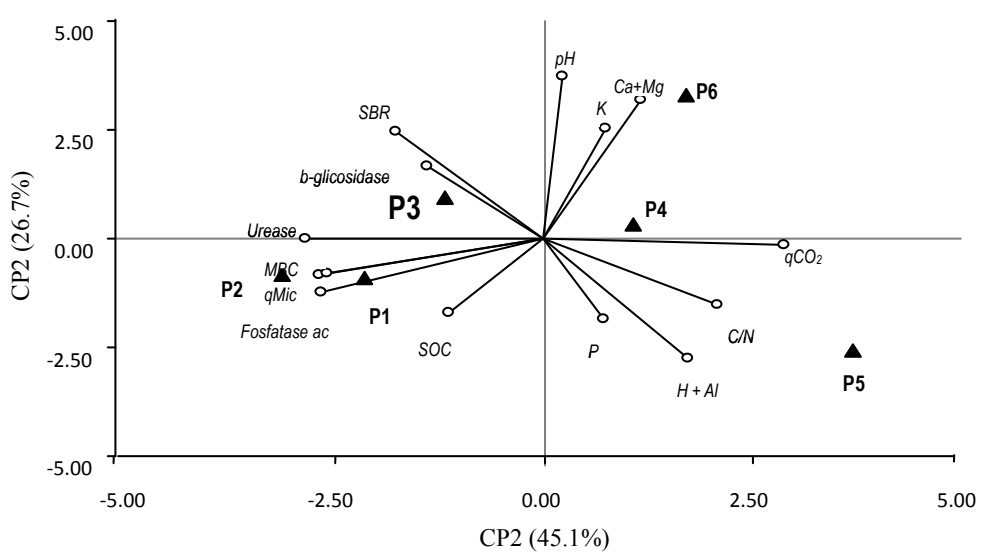

Figure 6. Ordination diagram (A- dry season; B- wet season) produced by Principle Component Analysis of chemical attributes $(\mathrm{P}, \mathrm{H}+\mathrm{Al}, \mathrm{K}, \mathrm{SOC}, \mathrm{C} / \mathrm{N}, \mathrm{Ca}+\mathrm{Mg})$; biological attributes $\left(\mathrm{MBC}, \mathrm{SBR}, \mathrm{qMIC}, \mathrm{qCO}_{2}\right)$; biochemical attributes (acid phosphatase, urease and $\beta$-glycosidase) of human-altered areas

Note. $\mathrm{P} 1$ = native forest; $\mathrm{P} 2$ = degraded pasture; $\mathrm{P} 3$ = managed pasture; $\mathrm{P} 4$ = area prepared for maize cultivation; $\mathrm{P} 5=$ area under preparation, recently deforested and burned; P6 = subsistence planting.

In $\mathrm{CP} 1$, the chemical attributes $\mathrm{SOC}$ and $\mathrm{pH}$ associated with the biological and biochemical attributes $\mathrm{MBC}$, qMIC, acid phosphatase and $\beta$-glycosidase were reduced during the dry season in P1, P2 and P3 soils. During this period, site P3 was not being grazed, so there was little pressure on the soil. In the wet season of the attributes measured, SOC, MBC, qMIC, acid phosphatase, $\beta$-glycosidase and urease appeared most closely 
linked with the quality of these environments. During this season, of all disturbed sites, P2 soil characteristic most resembled those of the control area of native vegetation (P1). These results are related to the availability, quantity and quality of organic material in various areas.

The quantity and quality of leaf litter, the higher complexity of plant structure, and the greater biological and microbiological diversity exerted a strong positive influence on both the biological and biochemical factors measured at site P1. Forested areas are also associated with higher levels of humidity, temperature and nutrient cycling, and this combination influences the microbiome, and chemical attributes as $\mathrm{pH}$ and $\mathrm{SOC}$, as well as biological (MBC and qMIC), and biochemical attributes ( $\beta$-glycosidase, acid phosphatase and urease) in both seasons.

Grasses and spontaneous plants, respectively, provided more readily-available plant material, mainly via roots, furnishing greater volumes of easy decomposed substrate at sites P2 and P3. This may well have had a positive influence on MBC and enzyme activity. Soil quality is derived from the balance between SOC and biological-plus-biochemical properties (Chaer et al., 2009).

Sites $\mathrm{P} 4$ and $\mathrm{P} 5$ showed positive correlations for $\mathrm{C} / \mathrm{N}, \mathrm{H}+\mathrm{Al}, \mathrm{P}, \mathrm{qCO}_{2}$ and negative correlations for SOC, dry period $\mathrm{pH}, \mathrm{MBC}$, qMIC, acid phosphatase and $\beta$-glycosidase, indicating a soil system imbalance as a consequence of human management, that had resulted in inefficient carbon use by the microbial community, thus reducing the quality of these soils.

$\mathrm{CP} 2$ showed a positive relation at site $\mathrm{P} 6$ between $\mathrm{Ca}+\mathrm{Mg}, \mathrm{K}$ and $\mathrm{pH}$, reflecting the importance of chemical attributes for soil quality. However, probably due to $\mathrm{pH}$ values and chemical conditions of the soil class of this area, the management form there did not favor biological and biochemical activity. This is in line with the results of Acosta-Martinez et al. (2007) in tropical watershed soils in Costa Rica.

\section{Conclusions}

Land use changes in the settlement area of Tepequém in the north of the Amazon, resulted in alterations to soil quality.

The spontaneous plants found on degraded pasture ensured system diversification, protection and organic contribution, facilitating resumption of ecological balancing of the soil.

Soil quality at managed pasture is attributed to the maintenance of soil cover, provided by grasses, and the absence of soil rotation.

Burning practices, soil disturbances and lack of cover negatively influenced the biological and enzymatic quality at sites in preparation and deforestation and burning.

Chemical attributes are significant factors influencing soil quality and health at subsistence plantation.

$\mathrm{MBC}, \mathrm{qMIC}$ and $\mathrm{qCO}_{2}$, acid phosphatase, $\beta$-glucosidase and urease were the most sensitive methods by which to differentiate sites in preparation from the native vegetation and pastures.

\section{Reference}

Acosta-Martinez, V., Dowd, S., Sun, Y., \& Allen, V. (2008). Tag-encoded pyrosequencing analysis of bacterial diversity in a single soil type as affected by management and land use. Soil Biology \& Biochemistry, 40(11), 2762-2770. https://doi.org/10.1016/j.soilbio.2008.07.022

Anderson, T.-H., \& Domesch, K. H. (2010). Soil microbial biomass: The eco-physiological approach. Soil Biology \& Biochemistry, 42(12), 2039-2043. https://doi.org/10.1016/j.soilbio.2010.06.026

Balzarini, M. G., \& Di Rienzo, J. A. (2013). InfoGen: Software estadístico para el análisis de datos genéticos. Córdoba, Argentina: FCA, Universidad Nacional de Córdoba.

Barbosa, R. I. (1993). Ocupação humana em Roraima: II. Uma revisão do equívoco da recente política de desenvolvimento e o crescimento desordenado. Boletim do Museu Paraense Emílio Goeldi, 9(2), 177-197. Retrieved from http://repositorio.inpa.gov/handle/123/5930

Barbosa, R. I. (1997). Distribuição das chuvas em Roraima. In R. I. Barbosa, E. J. G. Ferreira, \& E. G. Castellón (Eds.), Homem, Ambiente e Ecologia no Estado de Roraima (pp. 325-335). Manaus, Brasil: INPA.

Barni, P. E., Feanrside, P. M., \& Graça, P. M. L. A. (2012). Desmatamento no sul do Estado de Roraima: Padrão de distribuição em função de projetos de assentamento do INCRA e de distância das principais rodovias (BR-174 \& BR-210). Acta Amazônica, 42(2), 195-204. https://doi.org/10.1590/S0044-59672012000200003

Boerner, R. E. J., Giai, C., Huang J., \& Miesel, J. R. (2008). Initial effects of fire and mechanical thinning on soil 
enzyme activity and nitrogen transformations in eight North American forest ecosystems. Soil Biology \& Biochemistry, 40(12), 3076-3085. https://doi.org/10.1016/j.soilbio.2008.09.008

Chaer, G. M., Myrold, D. D., \& Bottomley, P. J. (2009). A soil quality index based on the equilibrium between soil organic matter and biochemical properties of undisturbed coniferous forest soils of the Pacific Northwest. Soil Biology \& Biochemistry, 41(4), 822-830. https://doi.org/10.1016/j.soilbio.2009.02.005

CPRM (Companhia de Pesquisa de Recursos Minerais). (2010). Carta Geológica: Folha NA 20-X-A-III, Vila de Tepequém. Roraima, Brazil.

EMBRAPA (Empresa Brasileira de Pesquisa Agropecuária). (2009). Manual de métodos de análise de solo (2nd ed.). Rio de Janeiro: Centro Nacional de Pesquisa de Solos.

Faria, A. F. G., Santos, A. C., Santos, T. M., \& Batistella Filho, F. (2010). Influência do manejo do solo nas propriedades químicas e físicas em topossequência na Bacia do rio Araguaia, Estado do Tocantins. Revista Brasileira de Ciências do Solo, 34(2), 517-524. https://doi.org/10.1590/S0100-06832010000200025.

Fearnside, P. M., Barbosa, R. I., \& Pereira, V. B. (2013). Emissões de gases do efeito estufa por desmatamento e incêndios florestais em Roraima: Fontes e sumidouros. Revista Agro@mbiente On-line, 7(1), 95-111. https://doi.org/10.18227/1982-8470ragro.v7i1.971

Hobley, E. U., Le Grey Brereton, A. J., \& Wilson, B. (2017). Forest burning affects quality and quantity of soil organic matter. Science of the Total Environment, 575, 41-49. https://doi.org/10.1016/j.scitotenv.2016.09.231

Jenkinson, D. S., \& Powlson, D. S. (1976). The effects of biocidal treatments on metabolism in soil. A method for measuring soil biomass. Soil Biology \& Biochemistry, 8(3), 209-213. https://doi.org/10.1016/0038-0717 (76)90005-5

Kandeler, E., \& Gerber, H. (1988). Short-term assay of soil urease activity using colorimetric determination of ammonium. Biology and Fertility of Soils, 6(1), 68-72. https://doi.org/10.1007/BF00257924

Kaschuk, G., Alberton, O., \& Hungria, M. (2010). Three decades of soil microbial biomass studies in Brazilian ecosystems: Lessons learned about soil quality and indications for improving sustainability. Soil Biology \& Biochemistry, 42(1), 1-13. https://doi.org/10.1016/j.soilbio.2009.08.020

Kotroczó, Z., Veres, Z., Fekete, I., Krakomperger, Z., Tóth, J. A., Lajtha, K., \& Tóthmérész, B. (2014). Soil enzyme activities in response to long-term organic matter manipulation. Soil Biology \& Biochemistry, 70, 237-243. https://doi.org/10.1016/j.soilbio.2013.12.028

Lal, R. (1988). Effects of macrofauna on soil properties in tropical ecosystems. Agriculture, Ecosystems and Environment, 24(1-3), 01-116. https://doi.org/10.1016/0167-8809 (88)90059-X

Lisboa, B. B., Vargas, L. K., Silveira, A. O., Martins, A. F., \& Selbach, P. A. (2012). Indicadores microbianos de qualidade do solo em diferentes sistemas de manejo. Revista Brasileira de Ciência do Solo, 36(1), 45-55. https://doi.org/10.1590/S0100-06832012000100004

Mangalassery, S., Mooney, S. J., Sparkes, D. L., Fraser, W. T., \& Sjögersten, S. (2015). Impacts of zero tillage on soil enzyme actives, microbial characteristics and organic matter functional chemistry in temperate soil. European Journal of Soil Biology, 68, 9-17. https://doi.org/10.1016/j.ejsobi. 2015.03.001

Matsuoka, M., Mendes, I. C., \& Loureiro, M. F. (2003). Biomassa microbiana e atividade enzimática em solos sob vegetação nativa e sistemas agrícolas anuais e perenes na região de Primavera do Leste (MT). Revista Brasileira de Ciência do Solo, 27(3), 425-433. http://doi.org/10.1590/S0100-06832003000300004

Medeiros, E. V., Duda, G. P., Santos, L. A. R., Lima, J. R. S., Almeida-Cortêz, J. S., Hammecker, C., \& Cournac, L. (2017). Soil organic carbon, microbial biomass and enzyme activities responses to natural regeneration in a tropical dry region in Northeast Brazil. Catena, 151, 137-146. https://doi.org/10.1016/j.catena.2016. 12.012

Melo, V. F., \& Schaefer, C. E. G. R. (2009). Matéria orgânica em solos desenvolvidos de rochas máficas no nordeste de Roraima. Acta Amazonica, 30(1), 53-60. https://doi.org/10.1590/S0044-59672009000100005

Melo, V. F., Schaefer, C. E. G. R., Fontes, L. E. F., Chagas, A. C., Lemos Júnior, J. B., \& Andrade, R. P. (2006). Caracterização física, química e mineralógica de solos da colônia agrícola do Apiaú (Roraima, Amazônia), sob diferentes usos e após queima. Revista Brasileira de Ciência do Solo, 30(6), 1039-1050. https://doi.org/ 10.1590/S0100-06832006000600013 
Mendes, I. C., Fernandes, M. F., Chaer, G. M., \& Reis Junior, F. B. (2012). Biological functioning of Brazilian Cerrado soils under different vegetation types. Plant and Soil, 359(1-2), 183-195. https://doi.org/10.1007/ s11104-012-1195-6

Pomianoski, D. J. W., Dedecek, R. A., \& Vilcahuaman, L. J. M. (2006). Efeito do fogo nas características químicas e biológicas do solo no sistema agroflorestal bracatinga. Boletim de Pesquisa Florestal, 52, 93-118.

RADAMBRASIL. (1975). Projeto RADAMBRASIL_Levantamento dos recursos naturais (Vol. 8). Rio de Janeiro, Brasil: Ministério do Meio Ambiente, Ministério das Minas e Energia.

Raiesi, F., \& Beheshti, A. (2015). Microbiological indicators of soil quality and degradation following conversion of native forests to continuous cropland. Ecological Indicators, 50, 173-185. https://doi.org/ 10.1016/j.ecolind.2014.11.008

Santos, H. G., Jacomine, P. K. T., Anjos, L. H. C., Oliveira, V. A., Oliveira, J. B., Coelho, M. R., \& Cunha, T. J. F. (2013). Sistema brasileiro de classificação de solos (3rd ed.). Rio de Janeiro: Embrapa Solos.

Silva, C. F., Pereira, M. G., Miguel, D. L., Feitosa, J. C. F., Loss, A., Menezes, C. E. G., \& Silva, E. M. R. (2012) Carbono orgânico total, biomassa microbiana e atividade enzimática do solo de áreas agrícolas, florestais e pastagem no médio vale do Paraíba do Sul (RJ). Revista Brasileira de Ciência do Solo, 36(6), 1680-1689. https://doi.org/10.1590/S0100-06832012000600002

Silva, L. G., Mendes, I. C., Reis Junior, F. B., Fernandes, M. F., Melo, J. T., \& Kato, E. (2009). Atributos físicos, químicos e biológicos de um Latossolo de cerrado em plantio de espécies florestais. Pesquisa Agropecuária Brasileira, 44(6), 613-620. https://doi.org/10.1590/S0100-204X2009000600010

Singh, D. (1981). The relative importance of characters affecting genetic divergence. Indian Journal of Genetic and Plant Breeding, 41(2), 237-245. Retrieved from http://indianjournals.com/ijor.aspx?target=ijor:ijgpb\& volume $=41 \&$ issue $=2 \&$ article $=010$

Soil Survey Staff. (2014). Keys to soil taxonomy (12th ed.). Washington, DC: United States Department of Agriculture, Natural Resources Conservation Service.

Tabatabai, A. (1994). Soil enzymes. In R. W. Weaver, J. S. Angle, P. Bottomley (Eds.), Methods of soil analyses. Part 2. Microbiological and biochemical properties (2nd ed., pp. 775-833). Madison, USA: Soil Science Society of America.

Udawatta, R. P., Kremer, R. J., Garrett, H. E., \& Anderson, S. H. (2009). Soil enzyme activities and physical properties in a watershed managed under agroforestry and row-crop systems. Agriculture, Ecosystems and Environment, 131(1-2), 98-104. https://doi.org/10.1016/j.agee.2008.06.001

Vance, E. D., Brookes, P. C., \& Jenkinson, D. S. (1987). Microbial biomass measurements in forest soils: Determination of $k_{c}$ values and test of hypotheses to explain the failure of chloroform fumigation-incubation method in acid soils. Soil Biology \& Biochemistry, 19(6), 689-696. https://doi.org/10.1016/0038-0717 (87)90050-2

Zuber, M., \& Villamil, M. B. (2016). Meta-analysis approach to assess effect of tillage on microbial biomass and enzyme activities. Soil Biology \& Biochemistry, 97, 176-187. https://doi.org/10.1016/j.soilbio.2016.03.011

\section{Copyrights}

Copyright for this article is retained by the author(s), with first publication rights granted to the journal.

This is an open-access article distributed under the terms and conditions of the Creative Commons Attribution license (http://creativecommons.org/licenses/by/4.0/). 